\title{
Analisis Kegiatan Public Relation Untuk Membangun Brand Awerness di PT Victory International Futures
}

\begin{tabular}{|c|c|}
\hline INFO ARTIKEL & Abstract \\
\hline $\begin{array}{l}\text { Sejarah Artikel: } \\
\text { Diterima : } \\
\text { Diperbaiki : } \\
\text { Disetujui } \quad: \\
\text { Keywords: } \\
\text { Public Relations, Brand Awerness }\end{array}$ & $\begin{array}{l}\text { Companies engaged in investing in futures, forex and precious metals index } \\
\text { products currently are very many kinds, so that in conditions like this cause a } \\
\text { lot of competition among companies, they create a strong brand to be widely } \\
\text { known in the community. In this case, Public Relations has a very important } \\
\text { role for the company to improve Brand Awarness. The focus of this research is } \\
\text { the role of Public Relations activities in increasing their awareness in PT. } \\
\text { Victoria International Future. This research method is a qualitative approach. } \\
\text { Public Relations activities can increase brand awareness for the company and } \\
\text { have a positive influence that can benefit the company. PT Victoria } \\
\text { International Futures is able to provide good service for its customers or even } \\
\text { those who are not yet customers and always build good relationships with } \\
\text { them, making it a superior company }\end{array}$ \\
\hline & Abstraks \\
\hline $\begin{array}{l}\text { Kata Kunci: } \\
\text { Public Relation, Brand Awerness } \\
\text { DOI: }\end{array}$ & $\begin{array}{l}\text { Perusahaan yang bergerak dalam bidang investasi pada produk indeks } \\
\text { futures, forex dan logam mulia saat ini sangat banyak sekali } \\
\text { macamnya,sehingga dalam kondisi yang seperti ini mengakibatkan } \\
\text { banyak persaingan diantara perusahaan-perusahaan, mereka } \\
\text { menciptakan brand yang kuat agar bisa dikenal secara luas di } \\
\text { masyrakat. Dlam hal tersebut maka Public Relatioan memiliki peran } \\
\text { yang sangat penting bagi perusahaan untuk meningkatkan Brand } \\
\text { Awarness. Fokus pada penelitian ini yaitu Peran kegiatan Public } \\
\text { Relation dalam meningkatkan kesadaran mereka di PT. Victoria } \\
\text { International Future. Metode penelitian ini adalah dengan pendekatan } \\
\text { kualitatif. Kegiatan Public Relation dapat meningkatkan Brand } \\
\text { Awarness bagi perusahaan dan memiliki pengaruh yang positif yang } \\
\text { dapat menguntungkan perusahaan. PT Victoria International Futures } \\
\text { mampu memberikan pelayan-pelayanan yang baik bagi customernya } \\
\text { mapupun masyarakat yang belum menjadi customernya dan selalu } \\
\text { membangun hubungan baik dengan mereka, sehingga menjadikannya } \\
\text { perusahaan yang unggul }\end{array}$ \\
\hline \multicolumn{2}{|c|}{\begin{tabular}{l|l} 
Koresponsi: & ISSN: 2355-9643 (Print) \\
Nama: Nur Lailiyah & ISSN: 2460-3775 (on-line) \\
Email: Laaiiyah2798@gmail.com p-ISSN: 2598-7763 &
\end{tabular}} \\
\hline
\end{tabular}

\section{PENDAHULUAN}

A. Latar Belakang Masalah

PT Victoria Internatioanal Futures ini merupakan perusahaan yang sudah diberi izin resmi dari PT Victoria Internatioanal Futures adalah sebuah perusahaan broker forex yang sudah memiliki pengalaman yang banyak sekali dalam melayani kliennya khususnya di bidang investasi, 
kegiatan investasi yang ada di PT Victoria International Futures meliputi indeks forex, futures dan logam mulia berjangka. Badan Pengawas Perdagangan Berjangka Komoditi (BAPPEPTI) dengan Nomor 18/BAPPEBTI/PN/42018. Perkembangan dunia bisnis saat ini menjadikan sebuah persaingan antar perusahaan satu dengan perusahaan lainnya, sebuah perusahaan harus bisa membangun dan memelihara kepercyaan konsumen terhadap barang dan jasa yang dihasilkan dari perusahaan. Merk atau brand merupakan identitas dari perusahaan yang membedakan dengan perusahaan lain maka dari itu sebuah perusahaan aakan menyadari bahwa merk merupakan elemen yang sangat penting untuk menhadapi persaingan bisnis gar perusahaan memiliki good image dan kepercyaaan yang baik di mata konsumennya. Brand Awerness merupakan kemampuan sebuah merk untuk muncul dalam benak konsumen ketika mereka sedang memikirkan kategori suatu produk tertentu dan seberapa mudahnya nama tersebut muncul (Shimp, 2004:121). Teknologi saat merupakan sebuah alat pendukung bisnis bagi suatu perusahaan, karena perkembangan zaman saat ini. Maka dari itu sebuah perusahaan harus bisa membangun sebuah kepercayaan kepada konsumennya melalui kecanggihan teknologi yang ada. Dengan banyaknya perusahaan menawarkan produknya kepada konsumen maka konsumen dapat lebih mudah mengingat dan mendapatkan kepuasan dari perusahaan tersebut.

Menurut Kartajaya (2009: 3), bahwa merek atau Brand berperan sebagai value indicator bagi seluruh stakeholder perusahaan (pelanggan, karyawan, serta investor), khususnya bagi pelanggan dan investor akan memilih produk atau Brand yang lebih terkenal dan akan mempertimbangkan hal tersebut. Mka ari itu dari suatu perusahaan diperlukan kegiatan Public Relation agar dapat membangun Brand Awerness dari konsumen, karena dengan adanya kegiatan ini akan sangat berpengaruh untuk membangun Brand Awerness terhadap masyarakat khususnya konsumen perusahaan.

Menanamkan Brand Awerness terhadap masyarakat mengenai bisnis ini sangat diperlukan, karena PT Victoria Internasional Futures bergerak di bidang derivative, dan tidak hanya itu saja konsumen tentunya ingin lebih mengetahui mengenai produk dan keunggulan yang ada di perusahaan maka Public Relation yang dilakukan melalui kegiatan seperti event, seminar, pengenalan produk melalui website appointmen dan sebgaainya. Event yang dilakukan PT Victoria Internasional Futures di mall-mall bisa memberikan pengetahuan baru mengenai bisnis ini karena di mall adalah tempat keramian yang sangat cocok dijadikan sebagai tempat event. Melalui seminar juga akan menjadi sebuah kegiatan trining dimana masyarakat atak konsumen bagaimana proses bisnis ini hal ini akan menjadikan konsumen smekain percaya dan tertarik untuk bergabung di PT Victoria Internasional Futures. Selain itu, kegiatan Public Relations tersebut dilakukan dengan menggunakan website, dengan tujuan siapapun dapat mengetahui mengenai bisnis ini melalui akses internet. Appointment sendiri adalah kegiatan dimana Public Relations PT Victory International Futures melakukan pertemuan dan pengenalan company profile secara personal dengan client yang sudah tercatat di data base perusahaan. Dengan kegiatan Public Relations tersebut sebagai upaya membangun Brand Awareness, bertujuan untuk menerapkan sebuah merek perusahaan di pikiran dan ingatan masyarakat, sehingga ketika masyarakat membicarakan mengenai yang berkitan dengan sebuah bisnis derivatif, maka mereka akan mengingat PT Victory International Futures sebagai perusahaan yang bergerak di bidang bisnis derivatif.

Dari pernyataan diatas peneliti ingin mengetahui bgaimana kegiatan Public Relation sebgai upaya membangun Brand Awerness PT Victory International Futures yang saat ini masih belum banyak diketahui oleh masyarakat tetapi dengan kegiatan yang dilakukan oleh Public Relation dapat membuktikan dan lebih meingkatkan kepercyaan konsumen juga untuk memelihara Brand Awerness terhadap konsumen. Untuk itu disini peneliti mengangkat judul "Analisis Kegiatan Public Relation Untuk Membangun Brand Awerness di PT Victory International Futures"

\section{B. Rumusan Masalah}

Bagaimana kegiatan Public Relation yang di lakukan PT Victory International Futures dalam membangun Brand Awerness?

\section{Tujuan Penelitian}

Untuk mengetahui apa saja yang menjadi kegiatan Public Relation sebagai upaya membangun Brand Awerness di PT Victory International Futures.

\section{Manfaat}

1. Manfaat bagi Perusahaan

Untuk mengevaluasi bagaimana kegiatan Public Relations yang tepat dalammembangun dan 
memelihara Brand Awareness untuk jangka panjang, dan menghadapi hambatan - hambatan Public Relations dalam menjalankan tugasnya.

2. Manfaat bagi masyarakat

Untuk menambah pengetahuan dan wawasan bagi pembaca mengenai kegiatan Public Relations sebagai upaya membangun Brand Awareness.

2. Kajian Teori

A. Public Relation

Public relations yaitu suatu kegiatan dalam menyampaikan opini public sebagai sesuatu yang menguntungkan anatara kedua belah pihak. Public relation merupakan sesuatu yang sangat penting untuk pencapaian tujuan dari sebuah organisasi. (Kustadi Suhandang 2004 : 44).

Public relation jika ditinjau secara etimologis terdiri dari dua suku kata yaitu pablic dan relations, yang artinya menurut kamus Bahasa Indonesia public berarti masyarakat dan relations berarti hubungan-hubungan, Menurut (Kustadi Suhandang 2004:44) Public relation berarti suatu hubungan-hubungan yang terjadi dengan masyarakat atau public.

Menurut (Frank Jefkins 2003:9) Public relation sangat berfungsi untuk membantu dan membangan komunikasi secara bersama, membangung dukungan dan kerjasama dalam manajemen. Public relations bertugas juga untuk melayani minat public, membantu untuk mengetahui dan merepon opini dari public, dan yang terpenting yaitu membantu manajemen untuk tetap memnfaatkan perubahan di zaman sekarang secra efektif untuk mengantisipasi trend. KPublic relations harus dilakukan secara berkesinambungan dah terencana agar dapat membantu menyukseskan sebuah organisasi atau perusahaan.

peranan utama dari public relations yaitu:

a. Publications (Publikasi dan publisitas) yaitu memperluas suatu informasi melalui berbagai sumber media tentang segala aktivitas yang dilakukan oleh perusahaan mana yang cocok atau tidak diketahui oleh public, agar akan memperoleh tanggapan yang baik dan positif dari masyarakat luas.

b. Event (Penyusunan program acara), yaitu kegiatan menyusun suatu acara tertentu dimana akan dipertontonkan kepada masyarakat luas maka harus diperhatikan waktu, tempat dan objeknya agar kegiatan event terlakasana dengan baik dan sempurna.

c. News (Menciptakan berita) yaitu harus pandai untuk menulis untuk menciptakan suatu berita yang baik, sesuai dengan kenyataan dan uptodate, misalnya menciptakan suatu berita.

d. Community involvement adalah yaitu suatu kegiatan untuk mengadakan kontak sosial dengan masyarakat luas tujuannya yaitu untuk menjaga hubungan yang bai kantar pihak organisasi atau perusahaan dengan masyarakat luas.

e. Inform or image yaitu kegiatan memberikan informasi kepada public untuk menarik perhatian, hasil yang diharaokan yaitu agar mendapatkan tanggapan yang positif dari public.

f. Lobbying and negotiation, yaitu kemmapuan untukmelobi danmelakukan negosiasi yang harus di miliki oleh public relations agar semua kegiatan yang dilakukan dapat terencana dengan baik dan ide, gagasan. Karena sebelum kegiatan dilakukan harus mengadakan suatu kegiatan yang tujuannya untuk melakukan pendekatan kepada masyarakat untuk menjcapai suatu kesepakatan agar memperoleh dukungan dari organisasi, sehingga akan saling menguntungkan untuk individu masyarakat dan organisasi.

g. Social Responsibility yaitu suatu aspek tanggung jawab sosial dari sebuah perusahaan yang tidak boleh hanya memikirkan keuntungan perusahaan saja tetapi juga kepedulian terhadap masyarakat untuk mencaoai sebuah kesuksesan dan memperoleh simpati dan enpati dari masyarakat. (Ruslan, 2005:9)

\section{B. Brand Awerness}

Menurut David A, Aaker (Ruslan:2010) Brandmerupakan symbol yang berfungsi untuk mebedakan anatar perusahan yang satu dengan perusahaan yang lainnya yang berbentuk seperti sebuah logo dari produk, cap produk mapun kemasan produk. Sedangkan pendapat yang dikemukakan oleh (Shimp:2004) Brand Awerness atau yang sering disebut dengan kesadaran merk merupakan kemampuan yang dimiliki oleh sebuah merk agar ketika melihat brand tersebut konsumen langsung memikirkan brand tersebut dan seberpa mudah nama brand tersebut muncul di benak konsumen.

Brand Awerness adalah kesanggupan yang dimiliki oleh calon pembeli untuk mengingat dan mengenali suatu merk tertentu yang mencari ciri khas yang dimiliki oleh suatu produk. (Durianto Dkk. 2004)

Berikut adalah beberapa tingkatan dari brand awerness dalam proses pembentukan kegiatan yang dilakukan oleh suatu perusahan 
yaitu :

1. Unaware Of Brand, yaitu pada tahap ini pelanggan akan merasa ragu terhadap suatu merk, tingakatan ini harus segera dihindari oleh perusahaan karena akan merugikan perusahaan.

2. Brand Recognitions, Yaitu pada tahap ini suatu pelanggan mulai mampu untuk mengidentifikasisuatu merk.

3. Brand recall, Yaitu pada tahap ini pelanggan mampu mengingat dan mengenali suatu merk tanpa harus diberikan stimulus terlebih dahulu.

4. Top of mind, Yaitu pada tahapan ini pelanggan mampu mengingat merk dengan apa yang dipikirkan oleh pelanggan saat sedang berbicara mengenai suatu kategori yang ada pada merk tertentu.

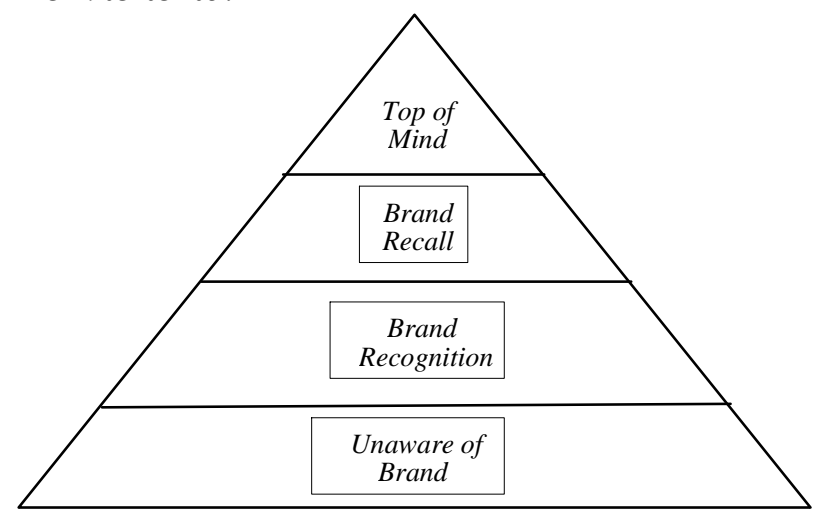

Gambar 1: Tingkatan Kesadaran Merek (Sumber: Durianto, Sugiarto dan Lie Joko Budiman, 2004)

Faktor Kesadaran Merek, Brand awerness dapat menandakan keberadaan merk ini merupakan sesuatu yang sangat penting bagi suatu perusahaan, jadi tingkat kesadaran merk yang tinggi akan dapat selalu kita rasakan, hal tersebut terjadi karena beberapa faktor yaitu :

- Mempromosikan produk secara luas sehingga produk tersebut mampu dikenali oleh masyarakat, seperti kegiatan promosi produk melalui iklan di televisi dan media sosial.

- Keberadaan suatu merk yang ada sudah sejak lama akan menunjukkan merk yang ada tersebut merupakan harapan konsumen yang mampu memenuhi kebutuhan konsumen.

- Proses distrubusi yang luas dan merata sehingga dimanapun tempat konsumen bereda mereka mampu mendapatkan produk tersebut dengan mudah.

- $\quad$ Merek tersebut dikelola dengan baik oleh perusahaan sehingga konsumen memiliki nilsi yang positif terhadap merk tersebut.

\section{METODOLOGI}

A. Pendekatan Penelitian

Penelitian yang saya lakukan ini menggunakan pendekatan penelitian kualitatif, Menurut (Sugiyono, 2009:15) Metode penelitian kualitatif merupakan sebuah metode penelitian yang berfokus pada filsafat positivism, yang diginakan peneliti untuk meneliti suatu obyek.

- Penelitian deskriptif kualitatif ditujukan untuk mendeskripsikan dan menggambarkan fenomenafenomena yang ada, baik bersifat alamiah maupun rekayasa manusia, yang lebih memperhatikan mengenai karakteristik, kualitas, keterkaitan antar kegiatan. (Sukmadinata 2011:73), B. Teknik Analisis Data

Menurut Sugiyono (2009: 91) Teknik analisis data dari suatu penelitian mencakup dari :

1. Reduksi Data (Data Reduction)

Reduksi data berarti kegiatan merangkum data yang dihasilkan selama proses penelitian dengan cara memilah hal-hal pokok yang diperoleh dengan hanya memfokuskan pada hal-hal penting saja dengan menentukan tema dan suatu polanya. Hal yang pertama kali dilakukan oleh peneliti yaitu melakukan reduksi data dengan begit dapt memudahkan peneliti untuk memaparkan infomasi mengenai public relations dan brand awerness di PT Victoria Internasional Futures. Ada beberapa langkah untuk melakukan reduksi data, langkah yang pertama yaitu meringkas dan mengelompokkan data, langkah yang kedua menyusun catatan-ctatan mengenai berbagai hal aktivitas dan proses-proses yang dilakukan perusahaan meliputi gagasan-gagasan dari narasumber yang mengarah pada teori dari data yang ditemukan, langkah terakhir dari reduksi data yaitu peneliti menyusun kembali konsep-konsep yang telah dijelaskan yang berkenaan dengan tema, pola-pola dan kelompok-kelompok yang bersangkutan.

\section{Penyajian Data (Data Display)}

Penelitian in melakukan penyajian data dengan cara mendeskripsikam hasil wawancara sesuai dengan jawabn yang diperoleh dari narasumber. Dengan melakuka display data maka akan memudahkan peneliti untuk memhamiapa yang sedang terjadi di suatu perusahaan. Untuk mengkaji suatu permasalahan maka penliti melakukan pengelolaan data hasil dari skor capaian responden yang dihasilkan dari masingmasing pertanyaan yang diberikan kepada narasumber,, Indikator dengan formulasi rumus menurut (Purwanto 1991:113) yaitu

untuksetiap indikator dengan formulasi 
rumus persentase yang dikemukakan oleh Purwanto (1991 : 113) sebagai berikut :

$\operatorname{Pr}=\frac{F}{N} \times 100 \%$

Keterangan :

$\mathrm{Pr}=$ Persentase capaian narasumber

$\mathrm{F}=$ Jumlah jawaban dari narasumber

$\mathrm{N}=$ Jumlah narasumber

$100 \%=$ Presentase jumlah tetap

3. Verifikasi (Verification)

Kesimpulan yang diberikan dari penelitian kualitatif ini kemundkinan dapat memberikan jawaban untuk setiap maslah yang telah dirumuskan oleh peneliti, tetapi kemungkinan lain juga tidak. Karena masalah dan rumusan masalah dalam penelitian kualitatif ini masih bersifat sementara dan akan berkembang setelah peneliti melakukan penelitian di lapangan. Verifikasi dalam penelitian ini merupakan hasil yang telah diperoleh oleh peneliti yang telah dilaksanakan dengan menggunakan pertanyaan singkat dan mudah untuk dipahami sehingga dapat menyimpulkan bagaimana kegiatan public relation untuk membangun brand awerness di PT Victory International Futures.

\section{HASIL PENELITIAN DAN PEMBAHASAN}

Hasil Penelitian yang diperoleh di lapangan sebagaimana tersaji pada uraian analisis data di atas, akan capaian persentase jawaban, kemudaian dicari relevansinya dengan teori-teori yang sudah ada. hasil temuan dengan teori Public Relation dan Brand Awerness. PT. Victoria International Futures telah melakukan berbagai aktivitas kegiatan untuk membangun kesadaran perusahaan mereka sebagai upaya untuk menghadapi persaingan bisnis yang sangat banyak dizaman sekarang ini apalagi karena kecanggihan teknologi yang ada. Dari persaingan yang ada PT. Victoria International Futures melakukan kegiatan pu lic relation sebagai upaya untuk menciptakan kesadaran mereka. Berdasarkan hasil penelitian kegiatan yang dilakukan Public Relation di PT. Victoria International Futures ;

1. Event yaitu yaitu kegiatan menyusun suatu acara tertentu dimana akan dipertontonkan kepada masyarakat luas maka harus diperhatikan waktu, tempat dan objeknya agar kegiatan event terlakasana dengan baik dan sempurna. Hal bertujuan untuk memperkenalkan suatu produk dan layanan perusahaan kepada masyarakat untuk mendekatkan diri ke public (N00r, 2009) Event yang dilakukan PT Victoria Internasional Futures di mall-mall bisa memberikan pengetahuan baru mengenai bisnis ini karena di mall adalah tempat keramian yang sangat cocok dijadikan sebagai tempat event. Kegiatan yang dilakukan di event tersebut ternyata berdampak positif bagi perusahaan karena ternyata masih banyak masyarakat yang belum mengetahui tentang PT. Victoria International Futures yang bisa dijadikan tempat $\mathrm{u}$ ntuk berinvestasi secara aman karena sudah mendapatkan izin resmi dari Badan Pengawas Perdagangan Berjangka Komoditi (BAPPEPTI). Setelah acara event banyak masyarakat yang ingn berinvestasi di PT. Victoria International Futures, dari sini perusahaan mendapatkan keuntungan karena customer mereka bertambah sehingga laba perusahaan meningkat

2. Seminar merupakan suatu kegiatan yang dilakukan untuk menyelesaikan atau memecahkan suatu permasalahan, yaitu dari kegiatan seminar bisa menemukan solusi yang bersumber dari penelitian atau literature. Seminar menjadi sebuah kegiatan trining dimana masyarakat atau konsumen akan mengetahui bagaimana proses bisnis ini hal ini akan menjadikan konsumen semakin percaya dan tertarik untuk bergabung di PT Victoria Internasional Futures. Ternyata ini juga sangat mempengaruhi masyarakat setelah kegiatan seinar dilakukan banyak yang tertarik untuk bergabung di Pt. Victotria International Futures dan mau berinvestasi sehingga menguntungkan perusahaan.

3. Website merupakan beberapa kumpulan file-file yang saling berkaitan yang terdiri atas halaman dan pagedari semua halaman-halaman yang terkait. Pt Victoria International Futures memiliki Website, dengan tujuan siapapun dapat mengetahui mengenai bisnis ini melalui akses internet. Appointment sendiri adalah kegiatan dimana Public Relations PT Victory International Futures melakukan pertemuan dan pengenalan company profile secara personal dengan client yang sudah tercatat di data base perusahaan. Terbukti dilihat dari systemyang ada banyak orang yang mengunjungi website yang dimiliki perusahaan karena ingin mengetahui informasi perusahaan secara lebih lengkap dan detail.

Semua kegiatan yang dilakukan Public Reation di PT Victory International Futures mengakui bahwa semua sangat berpengaruh dalam meningkatkan Brand Awerness perusahaan. Mengadakan keiatan-kegiatan yang menarik dapat meningkatkan citra perusahaan menjadi lebih baik, kegiatan yang dilakukan sangat berpengaruh positif bagi perusahaan dari masyarakat banyak 
yang belum mengetsshui perusahaan PT Victory International Futures jadi lebih mengetahui.

Agar sebuah proses perencanaan, pelaksanaan dan pengevaluasian yang dilakukan oeh Public Relation berjalan dengan lancar dan sesuai dengan apa yang menjadi tujuan perusahaan maka Public Relation harus dapat melakukan kegiatan-kegiatan dengan melalui proses dan komunikasi yang baik agar informasi yang disampaikan dapat memberikan dampak positif bagi perusahaan. Kegiatan Public Relations tersebut dilakukan dengan menggunakan. Dengan kegiatan yang Public Relations tersebut sebagai upaya membangun Brand Awareness, bertujuan untuk menerapkan sebuah merek perusahaan di pikiran dan ingatan masyarakat, sehingga ketika masyarakat membicarakan mengenal berkitan dengan sebuah bisnis derivatif, maka mereka akan mengingat PT Victory International Futures sebagai perusahaan yang bergerak di bidang bisnis derivative.

PT Victory International Futures memiliki ciri khas logo 2 segitiga yang bertumpukan dengan warna biru dan kuning yang dibawah logo tersebut bertukiskan "PT VICTORIA INERNATIONAL FUTURES" Pembentukan identitas diatas merupakan sebuah logo dimana logo merupakan cara untuk meningkatkan Brand Awerness masyarakat terhadap sebuah perusahaan, jika sebuah perusahaan tidaj memilki logo maka hal itu akan meningkatkan keraguan dan pikiran negative dari masyarakat bagi perusahaan tersebut.

PT Victory International Futures mampu memperkenalkan perusahaannya dalam kegiatankegiatan yang dilakukan ole public relationship dengan sangat baik dan menarik sehingga customer banyak yang tertarik untuk bergabung dengan PT Victory International Futures, serta PT Victory International Futures mampu memberikan pelayan-pelayanan yang baik bagi customernya mapupun masyarakat yang belum menjadi customernya dan selalu membangun hubungan baik dengan mereka, sehingga menjadikannya perusahaan yang unggul dibandingkan dengan perusahaan lainnya yang sejenis.

\section{KESIMPULAN DAN SARAN}

Victoria Internatioanal Futures ini merupakan perusahaan yang sudah diberi izin resmi dari PT Victoria Internatioanal Futures adalah sebuah perusahaan broker forex yang sudah memiliki pengalaman yang banyak sekali dalam melayani kliennya khususnya di bidang investasi, kegiatan investasi yang ada di PT Victoria International
Futures meliputi indeks forex, futures dan logam mulia berjangka. Badan Pengawas Perdagangan Berjangka Komoditi (BAPPEPTI). Dalam meningkatkan Brand Awernessya PT Victoria International Futures sudah menerapkan beberpa kegiatan melalui Public Relation, kegiatan yang dilakukan seperti event, seminar, pengenalan produk melalui website appointmen dan sebagainya. Dari kegitaan ini PT Victoria International Futures menciptakan citra yang positif sehingga menimbulkan kepercayaan bagi masyarakay dari kepercayaan timbullah keinginan mereka untuk lebih mengenal kemudian akan memutuskan bergabung dengan perusahaan sehingga perusahaan mendapatkan keuntungan.

PT Victoria International Futures mampu memberikan pelayan-pelayanan yang baik bagi customernya mapupun masyarakat yang belum menjadi customernya dan selalu membangun hubungan baik dengan mereka, sehingga menjadikannya perusahaan yang unggul dibandingkan dengan perusahaan lainnya yang sejenis.

\section{DAFTAR PUSTAKA}

Bahruansyah, Muhammad Anza. (2018). Pengaruh bauran promosi dan brand awareness terhadap minat beli topi kulit eervoleather. Jurnal Manajemen Strategi dan Aplikasi Bisnis, Vol 1, No.1, Desember 2018, pp. 37 46 eISSN 2655-237X

Prastya, Narayana Mahendra. (2016). Problem Struktural dalam Praktek Peran Manajerial Public Relations: Kasus Indonesia. Jurnal komunikasi Vol. 8, No. 2, Desember 2016, Hal 107 - 119

Wahid, Umaimah dan Anggun Eka Puspita. (2017). Upaya Peningkatkan Brand Awareness PT. Go-Jek Indonesia Melalui Aktivitas Marketing Public Relations. Jurnal Komunikasi Vol. 9, No. 1, Juli 2017, Hal 31 43 